\title{
Analisis Keterampilan Berpikir Kritis: Pengaruh Model Pembelajaran SiMaYang Berbantuan Concept Map pada Materi Struktur dan Fungsi Jaringan
}

\section{Analysis of Critical Thinking Skills: The Effect of a SiMaYang Assisted Concept Map Learning Model on Network Structure and Function Material}

\author{
Laila Puspita $^{1 *}$, Reva Antika Putri ${ }^{1}$, Komarudin $^{1}$ \\ Indonesia, 35131 \\ *Email Koresponden: lailapuspita@radenintan.ac.id \\ doi: http://dx.doi.org/10.29405/j.bes/4182-894782 \\ Received: 12 Maret 2020 \\ | Accepted: 16 Mei 2020 \\ | Published: 30 Juni 2020
}

${ }^{1}$ Universitas Islam Negeri Raden Intan Lampung. Jalan H. Endro Suratmin Sukarame, Bandar Lampung, Lampung,

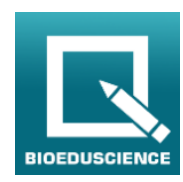

Abstrak

Background: Keterampilan berpikir kritis merupakan salah satu aspek penting bagi peserta didik dalam proses pembelajaran. Hal ini dikarenakan penggunaan keterampilan berpikir kritis yang tepat akan membantu peserta didik dalam meningkatkan keterampilan pemecahan masalah. Penelitian ini bertujuan untuk mengetahui pengaruh model pembelajaran SiMaYang berbantuan concept map terhadap keterampilan berpikir kritis peserta didik pada materi struktur dan fungsi jaringan. Metode: Metode penelitian yang digunakan adalah quasi eksperimen. Pengambilan sampel menggunakan teknik cluster random sampling. Adapun data diambil dengan menggunakan teknik tes, yaitu data tentang keterampilan berpikir kritis peserta didik. Instrumen tes tersebut berupa soal uraian (essay) yang dikembangkan berdasarkan indikator keterampilan berpikir kritis. Adapun analisis data yang digunakan yaitu uji-t Independent. Hasil: Berdasarkan hasil analisis data diperoleh bahwa nilai $t_{\text {hitung }}=5.94$ sedangkan $t_{\text {tabel }}=1.67$-sehingga $t_{\text {hitung }}>t_{\text {tabel }}$. Kesimpulan: Hal ini menunjukan Ho ditolak, sehingga dapat disimpulkan bahwa ada pengaruh pengaruh model pembelajaran SiMaYang berbantuan concept map terhadap keterampilan berpikir kritis peserta didik pada materi struktur dan fungsi jaringan.

Kata kunci: Model pembelajaran SiMaYang; concept map; berpikir kritis; struktur dan fungsi jaringan

\section{Abstract}

Background: Critical thinking skills are one of the most important aspects of learners in the learning process. It's because using the right critical thinking skills will help learners improve their problem-solving skills. This research aims to determine the influence of the learning model of SiMaYang with the concept map of the students 'critical thinking skills on the material structure and function of the network. Methods: The research method used is the quasi experiment. Sampling uses a random sampling cluster technique. The data is taken using the test technique, which is data on the critical thinking skills of learners. The test instrument is a description of the essay developed based on the indicators of critical thinking skills. The analysis of the data used is the Independent test-T. Results: Based on data analysis results obtained that value $t_{\text {obs. }}=5.94$ whereas $t_{\text {table }}=1.67$ so that $t_{\text {obs. }}>t_{\text {table }}$. Conclusions: his shows that Ho was rejected, so that it could be concluded that there was an influence on the influence of the learning model of the concept map of the students 'critical thinking skills on the material structure and function of the network

Keywords: SiMaYang learning model; concept map; critical thinking; structure and network function.

Cara citasi: Puspita, L., Putri, R.A., Komarudin. 2020. Analisis Keterampilan Berpikir Kritis: Pengaruh Model Pembelajaran SiMaYang Berbantuan Concept Map Pada Materi Struktur dan Fungsi Jaringan. BIOEDUSCIENCE: Jurnal Pendidikan Biologi dan Sains. 04(01): 82-89. Doi: http://dx.doi.org/10.29405/j.bes/4182-894782

(C) 2020 Oleh Bioeduscience: Jurnal Pendidikan Biologi dan Sains, Uhamka, Jakarta. Artikel ini bersifat open access yang didistribusikan di bawah syarat dan ketentuan Creative Commons Attribution (CC-BY) license. (http://creativecommons.org/licenses/by/4.0/). 


\section{PENDAHULUAN}

Manusia memiliki akal pikiran yang dapat menstimulasi pengetahuan dalam mengetahui, menjelaskan dan menyelesaikan masalah. Pendidikan dapat memberikan manusia pengetahuan sehingga dapat meningkatkan keterampilan maupun intelektualnya. Oleh karena itu pendidikan menjadi penting, karena dapat merubah tingkah laku dan sikap seseorang menjadi lebih baik, yaitu dengan adanya pengajaran/pembelajaran (Puspita, Yetri, \& Novianti, 2017). Pembelajaran adalah suatu proses dalam pendidikan, yang merupakan perubahan perilaku berawal tidak mampu menjadi mampu (Mudlofir, Fatimatur, \& Rusydiyah, 2016). Pembelajaran setidaknya memiliki tiga ranah, yaitu afektif, prikomotorik dan koognitif.

Proses pembelajaran membutuhkan model pembelajaran yang tepat untuk menunjang ketiga ranah tersebut. Model pembelajaran erat kaitanya dengan suasana proses pembelajaran, semakin tepat model pembelajaran, maka suasana pembelajaran juga akan semakin baik, sehingga mampu meningkatkan keaktifan, keterampilan berpikir kritis, maupun kreatif (Komarudin, Sujadi, \& Kusmayadi, 2014; Sudarisman, 2015). Tetapi prakteknya, pembelajaran di kelas masih tergolong pasif (Dian, 2017; Rolia, Rosmaiyadi, \& Husna, 2017). Selain itu, keterampilan berpikir kritis peserta didik masih tergolong rendah (Prani, Eka, \& Hidayat, 2017; Yasin et al., 2019), dan banyak peserta didik yang kurang bersemangat dan mudah menyerah dalam menggunakan keterampilan berpikir untuk menyelesaikan suatu masalah (Nastitisari, Sulistiana, Supriadi, \& Putra, 2018).

Permasalahan tersebut dapat menjadi indikasi tidak tepatnya penggunaan model pembelajaran yang digunakan, sehingga keterampilan berpikir kritis peserta didik belum maksimal, padahal keterampilan berpikir kritis merupakan salah satu keterampilan yang dibutuhkan bagi peserta didik (Kartikawati, Sulistyaning, \& Pratama, 2017; Nurlaila, Suparmi,
\& Sunarno, 2013; Velina, Nurhasanah, \& Zulhannan, 2017).

Pentingnya keterampilan berpikir kritis tersebut didukung dengan adanya penelitian sebelumnya yang membahas tentang keterampilan berpikir kritis. Švecová, et.al., dan Chukwuyenum dalam penelitianya menyatakan bahwa dalam proses pembelajaran, hendaknya menerapkan dan mengasah keterampilan berpikir kritis (Chukwuyenum \& Nelson, 2013; Švecová, Rumanova, \& Pavlovičová, 2014). Selanjutnya Duron, Limbach and Waugh dalam penelitianya dijelaskan bahwa hendaknya dalam pembelajaran ditekankan keterampilan berpikir kritis siswa, hal ini bertujuan agar menghasilkan pengalaman belajar yang lebih menyenangkan dan berharga baik bagi siswa maupun bagi guru (Duron, Limbach, \& Waugh, 2006). Dan Gueldenzoph dan Snyder dalam penelitianya menyatakan bahwa berpikir kritis penting karena dengan berpikir kritis secara otomatis seseorang akan mampu menyelesaikan permasalahan yang sederhana maupun kompleks dalam kehidupan sehari-hari (Gueldenzoph \& Snyder, 2008).

Berdasarkan beberapa hasil penelitian tersebut dapat dikatakan bahwa keterampilan berpikir kritis sangat dibutuhkan peserta didik untuk menyelesaikan masalahnya, karena dapat diselesaikan dengan interpretasi melalui tindakan eksplorasi terhadap suatu masalah, menerima masalah, sebagai respon terhadap situasi dengan memberikan pendapat (Rahma, Farida, \& Suherman, 2017). Berpikir kritis memiliki 5 indikator yakni 1) memberikan penjelasan sederhana; 2) membangun keterampilan dasar; 3) menyimpulkan; 4) memberikan penjelasan lanjut; 5) mengatur strategi dan taktik (Lestari, 2014; Maulana, 2018).

Keterampilan berpikir kritis peserta didik diharapkan dapat meningkat seiring dengan penggunaan model pembelajaran SiMaYang. Model pembelajaran SiMaYang merupakan model pembelajaran yang dikembangkan oleh Sunyono pada tahun 2012 (Meidiyanti, 2016). Model tersebut berbasis pada multipel representasi dengan empat fase yaitu orientasi, 
eksplorasi-imajinasi, internalisasi, dan evaluasi (Anggi, Pradina, Sunyono, \& Efkar, 2015; Meidiyanti, 2016; Suryani, Sunyono, \& Efkar, 2015; Tugiyah, Sunyono, \& Efkar, 2015). Fase tersebut disusun dalam bentuk layang-layang dan selanjutnya dinamakan Si-5 layang-layang atau disingkat SiMaYang.

Konsep-konsep fenomena sains yang diajarkan membutuhkan starategi yang dapat mempermudah memahami materi pelajaran yaitu dengan menggunakan Concept Map (Aminatul \& Susilaningsih, 2018; Puspita et al., 2017). Concept Map memberikan hasil yang baik pada keterampilan berpikir kritis peserta didik (Darusman, 2014a; Nastitisari \& Riandi, 2016).

Berdasarkan beberapa penelitian yang dilakukan sebelumnya, model pembelajaran SiMaYang dapat meningkatkan Keterampilan Proses Sains (Aprian, Dwi, Sunyono, \& Efkar, 2017), dapat meningkatkan self-efficacy (Meidayanti, Sunyono, \& Tania, 2015), dapat meningkatkan keterampilan metakognisi (Nurmala, Sunyono, \& Tania., 2015), dapat meningkatkan penguasaan konsep peserta didik (Anwar, Sunyono, \& Kadaritna, 2015; Hasibuan, Sari, \& Setiawaty, 2019; Setiatun, Sunyono, \& Rosilawati, 2018). Namun, belum adanya penelitian yang menerapkan model pembelajaran SiMaYang berbantuan mind map terhadap keterampilan berpikir kritis peserta didik. Argumen-argumen yang disebutkan memberikan gambaran perlunya melakukan penelitian untuk mengetahui pengaruh model pembelajaran SiMaYang berbantuan mind map terhadap keterampilan berpikir kritis peserta didik pada materi struktur dan fungsi jaringan pada tumbuhan.

\section{MATERI DAN METODE}

Penelitian ini termasuk dalam quasi eksperimen, karena dalam penelitian ini melihat pengaruh dari suatu perlakuan. Desain penelitian ini adalah posttest only control design.

Populasi dalam penelitian ini adalah peserta didik kelas XI IPA. Pengambilan sampel penelitian dilakukan dengan teknik cluster random sampling, yaitu teknik memilih sebuah sampel berdasarkan kelompok-kelompok kecil, atau cluster yang ada. Pada penelitian ini, sampel dikelompokkan menjadi dua kelompok, yaitu kelompok pertama yang beri perlakuan model pembelajaran SiMaYang berbantuan mind map dan kelompok kedua yang tidak diberi perlakukan dengan model pembelajaran SiMaYang berbantuan mind map (konvensional). Adapun sampel kelompok pertama yaitu kelas XI IPA-2 sebagai kelas eksperimen dan kelompok kedua yaitu kelas XI IPA-4 sebagai kelas kontrol.

Pengambilan data dilakukan dengan menggunakan teknik tes. Adapun tujuan dari teknik tersebut yaitu untuk mendapatkan data keterampilan berpikir kritis peserta didik pada materi struktur dan fungsi jaringan pada tumbuhan. Adapun instrumen tes tersebut berupa soal uraian (essay) yang dikembangkan berdasarkan indikator keterampilan berpikir kritis, yaitu: memberikan penjelasan sederhana (elementary clarification), membangun keterampilan dasar (basic support), menyimpulkan (inference), memberikan penjelasan lanjut (advence clarification), mengatur strategi dan taktik (strategy and tactics). Pengambilan data dilakukan setelah sampel mendapatkan treatment berupa model pembelajaran SiMaYang. Data yang telah dikumpulkan kemudian dianalisis menggunakan uji-t Independent dengan taraf signifikansi 0,05.

\section{HASIL}

Hasil analisis data keterampilan berpikir kritis peserta didik kelas eksperimen dan kelas memberikan gambaran bahwa model pembelajaran SiMaYang berbantuan Concept Map memberikan peningkatan terhadap keterampilan berpikir kritis karena dengan ini dapat mempermudah peserta didik dalam mempelajari materi pembelajaran (Tabel 1.). 
Tabel 1. Hasil Pengujian Instrumen

\begin{tabular}{lcc}
\hline \multicolumn{1}{c}{ Variabel } & Kelas Eksperimen & Kelas Kontrol \\
\hline Jumlah peserta didik & 30 & 30 \\
Rata-rata Skor Keterampilan Berpikir Kritis & 77,58 & 64,63 \\
Persentase Skor Keterampilan Berpikir Kritis & $78,4 \%$ & $65 \%$ \\
Standar Deviasi & 7,42 & 9,29 \\
\hline
\end{tabular}

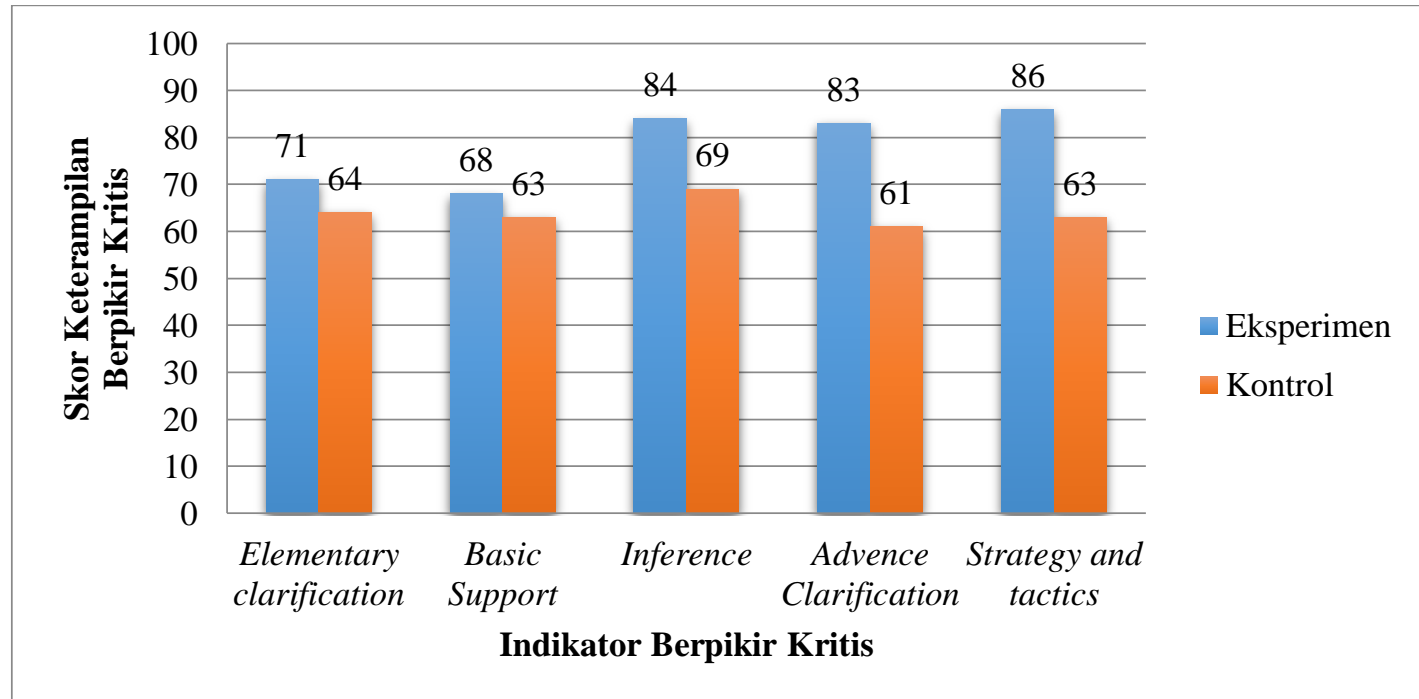

Gambar 1. Capaian Keterampilan Berpikir Kritis untuk masing-masing Indikator pada Kelas Eksperimen dan Kelas Kontrol

Tabel 1 di atas memperlihatkan bahwa kelas eksperimen lebih tinggi dibandingkan dengan kelas kontrol. Selanjutnya sebelum dilakukan uji hipotesis terlebih dahulu dilakukan uji prasyarat yaitu uji normalitas dan uji homogenitas. Uji normalitas dilakukan untuk melihat data berdistribusi normal atau tidak. Uji normalitas yang digunakan adalah uji Liliefors dengan taraf signifikan $0,05 \%$. Hasil perhitungan disajikan pada tabel 2. Selanjutnya dilakukan perhitungan terhadap uji normalitas dengan menggunakan uji Fisher. Hasil uji perhitungan disajikan dalam tabel 3. Yang terakhir uji hipotesis menggunakan $u j i-t$ Independent dengan effect size besar yang berarti memiliki pengaruh yang besar. Tabel 4 memperlihatkan bahwa nilai t_hitung $=5.94$ sedangkan t_tabel $=1.67$ sehingga t_hitung> t_tabel atau dengan kata lain H_0 ditolak, yang artinya model pembelajaran SiMaYang berbantuan concept map memberikan pengaruh terhadap keterampilan berpikir kritis peserta didik pada materi struktur dan fungsi jaringan.

Tabel 2. Hasil Uji Normalitas

\begin{tabular}{lllll}
\multicolumn{1}{c}{ Kelas } & $\boldsymbol{L}_{\text {hitung }}$ & $\boldsymbol{L}_{\text {tabel }}$ & \multicolumn{1}{c}{ Indeks } & \multicolumn{1}{c}{ Interpretasi } \\
\hline Eksperimen & 0,08557 & 0,161 & $L_{\text {hitung }}<L_{\text {tabel }}$ & $\begin{array}{l}\text { Data } \\
\text { Berdistribusi } \\
\text { Kontrol }\end{array}$ \\
\cline { 1 - 3 } & 0,09596 & 0,161 & & Normal \\
\hline
\end{tabular}


Tabel 3. Hasil Uji Homogenitas

\begin{tabular}{cccc}
\hline Jenis Tes & $\boldsymbol{F}_{\text {hitung }}$ & $\boldsymbol{F}_{\text {tabel }}$ & Interpretasi \\
\hline Posttest keterampilan berpikir kritis & 1.571 & 1.860811 & Homogen \\
\hline
\end{tabular}

Tabel 4. Hasil $U j i-t$ Independent

\begin{tabular}{crcc}
\hline Jenis Tes & $\boldsymbol{t}_{\text {hitung }}$ & $\boldsymbol{t}_{\text {tabel }}$ & Kesimpulan \\
\hline Posttest keterampilan berpikir kritis & 5.942510 & 1.671553 & $H_{0}$ ditolak \\
\hline
\end{tabular}

\section{PEMBAHASAN}

Berdasarkan penelitian yang telah dilakukan bahwa model pembelajaran SiMaYang berbatuan Concept Map memberikan pengaruh yang besar terhadap keterampilan berpikir kritis peserta didik. Hal ini terjadi karena proses pembelajaran SiMaYang dapat membangkitkan keaktifan dan semangat yang berdampak terhadap interaksi positif antara peserta didik dengan pendidik. Terjadi interaksi yang edukatif anatara peserta didik dengan pendidik merupakan pembelajaran yang baik (Hanafy, 2014). Model pembelajaran SiMaYang berbantuan Concept Map memberikan pengaruh terhadap peningkatan keterampilan berpikir kritis peserta didik. Hal ini dapat dilihat dari persentase skor keterampilan berpikir kritis kelas ekperimen adalah sebesar 78,4\% sedangkan pada kelas kontrol persentase diperoleh sebesar $65 \%$, dari hasil tersebut menunjukan bahwa kelas eksperimen lebih tinggi daripada kelas kontrol.

Sains mempelajari fakta, prinsip, teori, dan hukum, sehingga pembelajaran biologi mencakup alam dan lingkungan sekitar, sehingga pada pembelajaran biologi tidak hanya mempelajari hal yang bersifat makro tetapi juga yang bersifat sub mikro maupun secara simbolik yang bersifat abstrak. Model pembelajaran SiMaYang merupakan model pembelajaran berbasis multipelrepresentasi dengan memiliki tiga level fenomena alam yaitu makro, sub mikro dan simbolik yang yang bersifat abstrak (Anwar et al., 2015). Keterampilan representasi peserta didik dapat meningkat dengan menerapkan pembelajaran yang menekankan imajinasi. Imajinasi didapatkan pada saat pembelajaran menggunakan model pembelajaran SiMaYang yang memiliki empat langkah yaitu: 1) apersepsi; 2) imajiansi-eksplorasi; 3) internalisasi; dan 4) evaluasi (Sunyono 2015).

Penggunaan Concept Map bertujuan untuk membantu peserta didik dalam memperoleh materi pembelajaran. Peserta didik secara berkelompok membuat Concept Map, dengan demikian dapat lebih mempermudah peserta didik untuk berpikir sehingga pengetahuan dapat berkembang. Menurut (Darusman, 2014), Concept Map mampu meningkatkan keterampilan berpikir peserta didik (Adiwijaya, Suarsini, \& Lukiati, 2016).

Meningkatkan keterampilan berpikir kritis peserta didik dalam pembelajaran dapat dilakukan dengan menggunakan model pembelajaran yang sesuai dengan kebutuhan peserta didik (Adiwijaya et al., 2016; Izzati, Sunyono, \& Efkar, 2015; Nurmala et al., 2015). Fase imajinasi-eksplorasi dapat meningkatkan keterampilan berpikir kritis. Fase imajinasi dapat dilihat saat peserta didik menginterpretasi dengan memberikan tanggapan atau komentar saat pendidik memberikan abstraksi sedangkan fase eksplorasi menekankan terhadap konseptual dengan kegiatan diskusi, eksperimen laboratorium/demonstrasi, mengamati tayangan animasi dan menelusuri informasi melalui jaringan internet (weblog/webpage) pada tahap ini dibantu dengan Concept Map.

Berpikir kritis adalah bagian dari berpikir tingkat tinggi (Abdullah, 2016; Saregar, Latifah, \& Sari, 2016). Berpikir kritis memiliki 5 indikator yakni 1) memberikan penjelasan sederhana; 2) membangun keterampilan dasar; 3) menyimpulkan; 4) memberikan penjelasan lanjut; 5) mengatur strategi dan taktik (Kurnia et al., 2014; Lestari, 2014; Maulana, 2018). 
Berdasarkan hasil perhitungan perindikator keterampilan berpikir kritis peserta didik dihasilkan bahwa kelas eksperimen $(78,4 \%)$ lebih besar daripada kelas kontrol (65\%). Kelas eksperimen indikator pertama memberikan penjelasan sederhana memiliki sub-indikator memfokuskan pertanyaan, menganalisis argument, dan menjawab pertanyaan dengan persentase sebesar $71 \%$ berkategori baik. Indikator kedua membangun keterampilan dasar menghasilkan persentase yaitu sebesar 68\% dengan kategori baik dengan sub-indikator mempertimbangkan hasil observasi dan mempertimbangkan kredibilitas suatu sumber. Indikator ketiga yaitu menyimpulkan dengan persentase sebesar $84 \%$ berkategori baik, memiliki sub-indikator membuat deduksi dan induksi serta mempertimbangkan hasil dan membuat keputusan dengan hasil. Indikator keempat memberikan penjelasan lebih lanjut mendapatkan hasil sebesar $83 \%$ dengan kategori baik sekali, sub-indikator mengidentifikasi asumsi dan mendefinikasikan istilah. Indikator kelima adalah mengatur startegi dan taktik memperoleh persentase sebesar $86 \%$ dengan kategori baik sekali sub-indikator memutuskan suatu tindakan.

Hasil keterampilan berpikir kritis kelas kontrol sebagai berikut: indikator pertama yaitu memberikan penjelasan sederhana menghasilkan persentase yaitu sebesar $64 \%$ dengan kategori cukup memiliki sub-indikator menganalisis argument memfokuskan pertanyaan, dan menjawab pertanyaan. Indikator kedua membangun keterampilan dasar persentase sebesar $63 \%$ dengan kategori cukup, dua subindikator yaitu, mempertimbangkan hasil observasi dan mempertimbangkan kredibilitas suatu sumber. Indikator ketiga hasil persentase yaitu sebesar $69 \%$ berkategori baik yaitu menyimpulkan, yang memiliki sub-indikator membuat induksi serta merpertimbangkan hasilnya, membuat deduksi serta mempertimbangkan hasil dan membuat keputusan. Keempat mendapatkan hasil sebesar $61 \%$ dengan kategori cukup indikatornya adalah memberikan penjelasan lebih lanjut, yang sub- indikatornya adalah mendefinikasikan istilah dan mengidentifikasi asumsi. Indikator kelima mengatur startegi dan taktikmemperoleh persentase sebesar $63 \%$ dengan kategori cukup, sub-indikatornya yakni memutuskan suatu tindakan. Hal tersebut menguatkan hasil penelitian (Adiwijaya, Suarsini, dan Lukiati 2016; Fujika, Anggereini, dan Budiarti 2015) yang menyebutkan bahwa kelas eksperimen memiliki rata-rata

persentase skor kemampuan berpikir kritis 79,5\% lebih tinggi dibanding kelas kontrol 70,2\%. Berdasarkan hasil tersebut, kelas eksperimen persentase tertinggi pada indikator kelima yaitu mengatur strategi dan taktik, sedangkan untuk kelas kontrol ada pada indikator ketiga yaitu menyimpulkan. Persentase terendah pada kelas eksperimen ada pada indikator pertama yaitu memberikan penjelasan secara sederhana dan pada kelas kontrol terendah ada di indikator ke empat yaitu memberikan penjelasan lanjutan.

\section{KESIMPULAN}

Berdasarkan hasil analisis data diperoleh bahwa nilai $t_{\text {hitung }}=5.94$ sedangkan $t_{\text {tabel }}=1.67$ sehingga $t_{\text {hitung }}>t_{\text {tabel }}$. Hal ini menunjukan bahwa Ho ditolak, sehingga dapat disimpulkan ada pengaruh pengaruh model pembelajaran SiMaYang berbantuan concept map terhadap keterampilan berpikir kritis peserta didik pada materi struktur dan fungsi jaringan.

\section{REFERENSI}

Abdullah, I. H. (2016). Berpikir kritis matematik. Delta-Pi: Jurnal Matematika Dan Pendidikan Matematika, 2(1).

Adiwijaya, H., Suarsini, E., \& Lukiati, B. (2016). Penerapan Pembelajaran Reciprocal Teaching Berbantuan Peta Konsep Untuk Meningkatkan Kemampuan Berpikir Kritis Siswa Pembelajaran Biologi.”. Jurnal Pendidikan, 1(2), 2379-2387.

Aminatul, A., \& Susilaningsih, E. (2018). Desain Media Peta Konsep Multi Representasi Pada Materi Buffer Dan Hidrolisis.”. Jurnal Inovasi Pendidikan Kimia, 12(1), 2055-2064.

Anggi, Pradina, O., Sunyono, \& Efkar, T. (2015). Perbandingan Simayang Tipe-II Dengan PBL Terhadap Kemampuan Metakognisi Dan Efikasi 
Diri. Jurnal Pendidikan Dan Pembelajaran Kimia, 4(3), 1036-1047.

Anwar, K., Sunyono, S., \& Kadaritna, N. (2015). Pembelajaran Model SiMaYang Tipe II untuk meningkatkan Model Mental dan Penguasaan Konsep. Jurnal Pendidikan Dan Pembelajaran Kimia, 4(3), 795-806.

Aprian, Dwi, R., Sunyono, \& Efkar, T. (2017). Pengaruh Strategi Scaffolding pada Pembelajaran SiMaYang dalam Meningkatkan Keterampilan Proses Sains. Jurnal Pendidikan Dan Pembelajaran Kimia, 6(1).

Chukwuyenum, \& Nelson, A. (2013). Impact of critical thinking on performance in mathematics among senior secondary school students in Lagos State. IOSR Journal of Research \& Method in Education, 3(5), 18-25.

Darusman, R. (2014a). Penerapan Metode Mind Mapping (Peta Pikiran) untuk Meningkatkan Kemampuan Berpikir Kreatif Matematik Siswa SMP. Jurnal Ilmiah Program Studi Matematika STKIP Siliwangi Bandung., 3(2), 164-172.

Darusman, R. (2014b). Penerapan Metode Mind Mapping (Peta Pikiran) untuk Meningkatkan Kemampuan Berpikir Kreatif Matematik Siswa SMP. Infinity Journal, 3(2), 164-173.

Dian, A. (2017). Identifikasi Masalah yang Dihadapi Guru Biologi dalam Pelaksanaan Pembelajaran pada Materi Ekosistem. BIOTIK: Jurnal Ilmiah Biologi Teknologi Dan Kependidikan, 3(1), 6368.

Duron, R., Limbach, B., \& Waugh, W. (2006). Critical Thinking Framework For Any Discipline. International Journal of Teaching And Learning In Higher Education, 17(2), 160-166.

Gueldenzoph, L., \& Snyder, M. J. (2008). Teaching Critical Thinking And Problem Solving Skills. The Journal Of Research In Business Education, 50(2), 90 .

Hanafy, M. S. (2014). Konsep Belajar dan Pembelajaran. Lentera Pendidikan: Jurnal Ilmu Tarbiyah Dan Keguruan, 17(1), 66-79.

Hasibuan, M. P., Sari, R. P., \& Setiawaty, S. (2019). Penerapan Model Pembelajaran Dengan Pendekatan Saintifik Terhadap Pembentukan Habits of Mind Siswa. JIPI (Jurnal IPA \& Pembelajaran IPA), 3(2), 119-129. https://doi.org/10.24815/jipi.v3i2.14415

Izzati, S., Sunyono, \& Efkar, T. (2015). Penerapan Simayang Tipe II Berbasis Multipel Representasi Pada Materi Asam Basa. Jurnal Pendidikan Dan Pembelajaran Kimia, 4(1), 262-274.

Kartikawati, Sulistyaning, \& Pratama, H. (2017). Pengaruh Penggunaan Whatsapp Messenger
Sebagai Mobile Learning Terintegrasi Metode Group Investigation Terhadap Kemampuan Berpikir Kritis. JUPITER (Jurnal Pendidikan Teknik Elektro), 2(2), 33-38.

Komarudin, Sujadi, I., \& Kusmayadi, T. A. (2014). Proses Berpikir Kreatif Siswa SMP Dalam Pengajuan Masalah Matematikaditinjau Dari Gaya Kognitif Siswa (Studi Kasus Pada Siswa Kelas Viii-H SMP Negeri 1 Sukoharjo Tahun Pelajaran 2012/2013). Jurnal Pembelajaran Matematika, 2(1).

Kurnia, R. D., Ruskan, E. L., Ibrahim, A., Informasi, S., Ilmu, F., Universitas, K., ... Universitas, K. (2014). Pengembangan Model Pembelajaran Berbasis Cooperative Learning dalam Meningkatkan Motivasi Belajar Mahasiswa dan Peningkatan Mutu Lulusan Alumni Fasilkom Unsri Berbasis E-Learning (studi kasus: matakuliah pemrograman web) 1,2,3.6(1), 645654.

Lestari, K. E. (2014). Implementasi Brain-Based Learning Untuk Meningkatkan Kemampuan Koneksi Dan Kemampuan Berpikir Kritis Serta Motivasi Belajar Siswa SMP. Judika (Jurnal Pendidikan UNSIKA), 2(1).

Maulana. (2018). Dasar-Dasar Konsep Peluang (L. P. Pramswari, Ed.). Bandung: UPI PRESS.

Meidayanti, R., Sunyono, S., \& Tania, L. (2015). Pembelajaran Simayang Tipe II Untuk Meningkatkan Self-Efficacy Dan Keterampilan Berpikir Kritis. Jurnal Pendidikan Dan Pembelajaran Kimia, 4(3), 856-867.

Meidiyanti, R. (2016). Pembelajaran Simayang Tipe II Untuk Meningkatkan Self Efficacy Dan Keterampilan Berpikir Kritis Pada Materi Larutan Elektrolit Dan Non-Elektrolit. Universitas Bandar Lampung.

Mudlofir, A., Fatimatur, E., \& Rusydiyah. (2016). Desain Pembelajaran Inovatif Dari Teori Ke Praktik. Jakarta: Rajawali Press.

Nastitisari, D., \& Riandi, R. (2016). Analisis Kemampuan Berpikir Kompleks Siswa Melalui Pembelajaran Berbasis Masalah Berbantuan Mind Mapping. EDUSAINS, 8(1), 98-107.

Nastitisari, D., Sulistiana, W., Supriadi, N., \& Putra, F. G. (2018). Model Hands On Mathematics (Hom) Berbantuan LKPD Bernuansa Islami Materi Garis Dan Sudut. Desimal: Jurnal Matematika, 1(1), 57-63.

Nurlaila, N., Suparmi, S., \& Sunarno, W. (2013). Pembelajaran Fisika Dengan PBL Menggunakan Problem Solving dan Problem Posing Ditinjau Dari Kreativitas dan Keterampilan Berpikir Kritis Siswa. Inkuiri, 2(2). 
Nurmala, V., Sunyono, \& Tania., L. (2015). Pembelajaran Simayang Tipe II Untuk Meningkatkan Kemampuan Metakognisi Dan Keterampilan Berpikir Kritis. 4(3), 832-843.

Prani, A., Eka, I., \& Hidayat, A. (2017). Penelitian Eksplanatori : Keterampilan Berpikir Kritis Siswa SMA Pada Materi Fluida Statis. Seminar Pendidika IPA Pascasarjana UM 2, 103-109.

Puspita, L., Yetri, Y., \& Novianti, R. (2017). Pengaruh Model Pembelajaran Reciprocal Teaching Dengan Teknik Mind Mapping Terhadap Kemampuan Metakognisi Dan Afektif Pada Konsep Sistem Sirkulasi Kelas Xi Ipa Di Sma Negeri 15 Bandar Lampung. Biosfer: Jurnal Tadris Biologi, 8(1), 78-90.

Rahma, S., Farida, \& Suherman. (2017). Analisis Berpikir Kritis Siswa Dengan Pembelajaran Socrates Kontekstual. Seminar Nasional Mateatika Dan Pendidikan Matematika, 121128.

Rolia, R., Rosmaiyadi, R., \& Husna, N. (2017). Pengaruh Model Pembelajaran Creative Problem Solving Terhadap Kemampuan Berpikir Kreatif Siswa Pada Materi Program Linier Kelas XI SMK. VOX EDUKASI: Jurnal Ilmiah Ilmu Pendidikan, 8(2), 72-82.

Saregar, A., Latifah, S., \& Sari, M. (2016). Efektivitas Model Pembelajaran Cups: Dampak Terhadap Kemampuan Berpikir Tingkat Tinggi Peserta Didik Madrasah Aliyah Mathla'ul Anwar Gisting Lampung. Jurnal Ilmiah Pendidikan Fisika AlBiruni, 5(2), 233-244.

Setiatun, S. N., Sunyono, S., \& Rosilawati, I. (2018). Pengaruh Scaffolding Dalam Pembelajaran Simayang Untuk Meningkatkan KPS Dan Penguasaan Konsep. Urnal Pendidikan Dan Pembelajaran Kimia, 7(1), 13-225.

Sudarisman, S. (2015). Memahami Hakikat Dan Karakteristik Pembelajaran Biologi Dalam Upaya Menjawab Tantangan Abad 21 Serta Optimalisasi Implementasi Kurikulum 2013. Florea: Jurnal Biologi Dan Pembelajarannya, 2(1), 29-35. https://doi.org/10.25273/florea.v2i1.403

Suryani, I., Sunyono, S., \& Efkar, T. (2015). Penerapan Simayang Tipe II Untuk Meningkatkan Model Mental Dan Penguasaan Konsep Siswa. Jurnal Pendidikan Dan Pembelajaran Kimia, 4(3), 807819.

Švecová, V., Rumanova, L., \& Pavlovičová, G. (2014). Support Of Pupil's Creative Thinking In Mathematical Education. Procedia-Social And Behavioral Sciences, 116, 1715-1719.

Tugiyah, Sunyono, \& Efkar, T. (2015). Perbandingan Simayang Tipe-II Dengan Discovery Learning Terhadap Kemampuan Metakognisi Dan
Penguasaan Konse. Jurnal Pendidikan Dan Pembelajaran Kimia, 4(3), 1073-1084.

Velina, Y., Nurhasanah, W., \& Zulhannan, Z. (2017). Pengaruh Strategi Pembelajaran Peningkatan Kemampuan Berpikir (SPPKB) Terhadap Kemampuan Berpikir Kritis Biologi Peserta Didik Kelas XI. Biosfer: Jurnal Tadris Biologi, 8(2), 67-83.

Yasin, M., Huda, S., Suherman, Komarudin, Septiana, R., \& Palupi, E. K. (2019). Mathematical Critical Thinking Ability: The Effect of Scramble Learning Model assisted by Prezi in Islamic School. 